\title{
Vanillin Analogues $o$-Vanillin and 2,4,6-Trihydroxybenzaldehyde Inhibit NFkB Activation and Suppress Growth of A375 Human Melanoma
}

\author{
ANNAMÁRIA MARTON ${ }^{1}$, ERZSÉBET KÚSZ ${ }^{1}$, CSONGOR KOLOZSI ${ }^{1}$, VILMOS TUBAK ${ }^{2}$, \\ GIUSEPPE ZAGOTTO $^{3}$, KRISZTINA BUZÁS $^{1}$, LUIGI QUINTIERI ${ }^{3 *}$ and CSABA VIZLER ${ }^{1 *}$ \\ ${ }^{1}$ Hungarian Academy of Sciences, Biological Research Centre, Szeged, Hungary; \\ ${ }^{2}$ Creative Laboratory Ltd, Szeged, Hungary; \\ ${ }^{3}$ Department of Pharmaceutical and Pharmacological Sciences, University of Padova, Padua, Italy
}

\begin{abstract}
Background/Aim: Constitutive activation of nuclear factor kappa-B $(N F K B)$ is a hallmark of various cancer types, including melanoma. Chemotherapy may further increase tumour $N F_{k} B$ activity, a phenomenon that, in turn, exacerbates drug resistance. This study aimed at preliminary screening of a panel of aromatic aldehydes, including vanillin, for cytotoxicity and suppression of tumour cell NFKB activity. Materials and Methods: The cytotoxic and $N F K B$-inhibitory effects of 10 aromatic aldehydes, including vanillin, were investigated in cultured A375 human melanoma cells. Each compound was assayed alone and in combination with the model $N F_{K} B$-activating drug doxorubicin. The most promising analogues were then tested alone and in combination with 4-hydroperoxycyclophosphamide in vitro, and with cyclophosphamide in mice bearing A375 xenografts. Results: The vanillin analogues o-vanillin and 2,4,6trihydroxybenzaldehyde exhibited cytotoxicity against cultured A375 cells, and inhibited doxorubicin- and 4-hydroperoxycyclophosphamide-induced $N F_{k} B$ activation. They also suppressed A375 cell growth in mice. Conclusion: o-vanillin and 2,4,6-trihydroxybenzaldehyde deserve further evaluation as potential anticancer drugs.
\end{abstract}

This article is freely accessible online.

*These Authors contributed equally as joint last authors

Correspondence to: Csaba Vizler, Hungarian Academy of Sciences, Biological Research Centre, Temesvári krt. 62, Szeged, H-6726, Hungary. E-mail: vizler.csaba@brc.mta.hu or Luigi Quintieri Department of Pharmaceutical and Pharmacological Sciences, University of Padova, Largo Meneghetti 2, 35131 Padova, Italy. E-mail: luigi.quintieri@unipd.it

Key Words: Melanomas, NFxB, vanillin, chemotherapy.
Nuclear factor kappa-B $(\mathrm{NFkB})$ is a transcription factor playing a crucial role in malignant diseases (1-4). Upregulation of $\mathrm{NFKB}$ activity is detected in various human tumours (5-7), including pancreatic adenocarcinoma (8), breast cancer (9), and melanoma (10), where it may contribute to malignant behaviour. In particular, $\mathrm{NFKB}$ activation has been associated with cancer development and progression $(5,11)$, and may inhibit apoptosis and favour cancer cell proliferation, invasion, angiogenesis, and metastasis $(12,13)$. Importantly, increased NFKB activation may induce tumour immune escape and chemotherapy resistance (14-16). Chemotherapy-induced cellular stress, in turn, might further increase NFKB activity of tumour cells, protecting them from chemotherapy-induced apoptosis (1719). Therefore, NFkB signaling pathways could serve as potential targets for cancer therapy.

Vanillin (4-hydroxy-3-methoxybenzaldehyde; compound 10 , Table I) is a major component of the bean and pod of some plant species of the Vanilla genus, and is also synthesized on a large scale for use as a flavouring agent in food, fragrance and pharmaceutical industries. Multiple biological effects have been documented for vanillin. It exhibits antioxidant $(20,21)$, antimicrobial (22), analgesic $(23,24)$ and anti-sickling $(25)$ properties. It was also proven to be an anticarcinogen in rats (26) and an antimutagen in a variety of in vitro models (27-29). Vanillin is relatively noncytotoxic towards cultured mammalian cells, but does potentiate the cytotoxicity of some DNA-damaging agents, including cisplatin (30) and mitomycin C (31), a property which correlates with its ability to impair DNA double-strand break repair via inhibition of DNA protein kinase (30). Although unable to suppress primary tumour growth itself, vanillin was found to exert anti-metastatic activity in the 4T1 mouse mammary carcinoma spontaneous metastasis model, and to inhibit tumour cell invasion and migration in vitro 
(32). More recently, vanillin was found to inhibit angiogenesis in a chick chorioallantoic membrane assay (33), and to suppress $\mathrm{NFkB}$ activation induced by various inflammatory stimuli including tumour necrosis factorrelated apoptosis-inducing ligand, tumour necrosis factor $\alpha$ (34), trinitrobenzene sulfonic acid (35), and 12-Otetradecanoylphorbol-13-acetate (36). The suppressive effect of vanillin on $\mathrm{NFKB}$ activity may be a major mechanism underlying its anti-invasive, anti-metastatic and antiangiogenic properties, and offers potential for developing novel anticancer agents. In particular, we reasoned that although vanillin itself exhibits little cytotoxic activity (30), it might sensitize tumour cells to anticancer drugs known to elicit NFKB activation, thus increasing the efficacy of chemotherapy regimens, as well as serve as a lead structure for the discovery of more effective analogues.

In this article, we report the results of in vitro experiments undertaken to screen a small set of structurally related aromatic aldehydes, including vanillin, for cytotoxic activity, and for inhibition of constitutive and chemotherapy-induced NFkB activity in human melanoma cells. Furthermore, we report the results of a trial in A375 human melanoma-bearing mice evaluating the efficacy of two selected aldehydes, namely $o$-vanillin and 2,4,6-trihydroxybenzaldehyde, as single agents and in combination with the $\mathrm{NFKB}$-inducing drug cyclophosphamide.

\section{Materials and Methods}

Chemicals and working solutions. The anticancer drugs doxorubicin (as hydrochloride salt) and cyclophosphamide, as well as all the aromatic aldehydes used throughout the study, including vanillin (4hydroxy-3-methoxybenzaldehyde; compound 10), the vanillin isomer $o$-vanillin (2-hydroxy-3-methoxybenzaldehyde; compound 7), and 2,4,6-trihydroxybenzaldehyde (compound 6) (see Table I), were obtained from Sigma-Aldrich (St. Louis, MO, USA). 4Hydroperoxycyclophosphamide (4-HC) was obtained from NiomechIIT GmbH (Bielefeld, Germany). Stock solutions of each aldehyde at $100 \mathrm{mM}$ were prepared in dimethyl sulfoxide (DMSO; SigmaAldrich), stored at $4^{\circ} \mathrm{C}$, and used within 6 weeks. Working solutions were prepared just before use by dilution of the stocks with cell culture medium (see below); the final concentration of DMSO in the culture medium never exceeded $0.25 \%$ (v/v). Suspensions for oral administration of $o$-vanillin and 2,4,6-trihydroxybenzaldehyde (TBA) were prepared just before use by dilution of the stock solutions with sterile phosphate-buffer saline (PBS). A stock solution of doxorubicin at $10 \mathrm{mM}$ was prepared in sterile sodium chloride $0.9 \%$ and kept at $-20^{\circ} \mathrm{C}$. 4-HC and cyclophosphamide were dissolved in sterile PBS immediately before use.

Cell culture and transfection. The A375 human melanoma cell line was originally obtained from the American Type Culture Collection, (Manassas, VA, USA) and maintained in Dulbecco's modified Eagle's medium/nutrient mixture F-12 (DMEM/F12) medium (Lonza, Basel, Switzerland) supplemented with $10 \%$ heatinactivated foetal bovine serum (FBS; Lonza). Cultures were grown at $37^{\circ} \mathrm{C}$ in a humidified atmosphere consisting of $5 \% \mathrm{CO}_{2} / 95 \%$ air. The NFkB reporter cell lines were obtained by transfection with the pNFkB-Luc/neo reporter construct using Lipofectamine 2000 reagent (Invitrogen, Carlsbad, CA, USA). In the Luciferase Assay System, the firefly luciferase was used as a reporter because the assay is very sensitive, has no background and the reporter activity is available immediately upon translation. As a transfection efficacy control, we used a plasmid encoding enhanced green fluorescent protein (pEGFP; Invitrogen); the transfection efficacy with the pEGFP vector was $78 \%$, as determined by flow cytometry 48 hours after transfection. Transfected cells were selected in the presence of G418 (200 $\mu \mathrm{g} / \mathrm{ml}$; Sigma).

Testing of NFKB activity in A375 cells stably transfected with an $N F k B$-luciferase reporter construct. A375 cells stably transfected with the $\mathrm{pNFKB}-\mathrm{Luc} / \mathrm{neo}$ indicator construct were plated at $3 \times 10^{4} /$ well on TC quality luminescent assay plates (Corning Incorporated, NY, USA) in $200 \mu \mathrm{l}$ of DMEM/F12 medium supplemented with $10 \%$ heat-inactivated FBS. After one-day culturing, the cells were treated with $10,5,2.5,1.25$, or $0.625 \mu \mathrm{M}$ doxorubicin in the absence or in the presence of $250 \mu \mathrm{M}$ of each of the selected aldehydes. 4-HC was also tested at $50,25,12.5,6.25$ and $3.125 \mu \mathrm{M}$ concentration alone and in combination with TBA or $o$-vanillin at $250 \mu \mathrm{M}$. After 6-hour incubation $\left(37^{\circ} \mathrm{C} ; 5 \% \mathrm{CO}_{2}\right)$, the medium was discarded; the cells were washed with $200 \mu \mathrm{l} \mathrm{PBS/well} \mathrm{(Promo} \mathrm{Cell,} \mathrm{Heidelberg,}$ Germany) and lysed with $20 \mu \mathrm{l}$ Cell Culture Lysis Reagent/well (Promega, Madison, WI, USA) for 5 minutes. After adding the firefly luciferase substrate $(20 \mu \mathrm{l} /$ well; Promega), luciferase activity was measured with Luminoscan Ascent Scanning Luminometer (Thermo Electron Corporation, Waltham, MA). Aldehydes exhibiting inhibition of drug-induced or constitutive (basal) NFKB activity greater than $20 \%$ were considered active compounds.

Cell viability assay. A375 human melanoma cells were seeded into flat-bottomed 96 -well plates $\left(1 \times 10^{4}\right.$ cells/well $)$ and allowed to attach for $24 \mathrm{~h}$. They were then grown $\left(37^{\circ} \mathrm{C} ; 5 \% \mathrm{CO}_{2}\right)$ for an additional $48 \mathrm{~h}$ in the absence (control) or in the presence of 250 $\mu \mathrm{M}$ of the tested aromatic aldehyde, or in the presence of increasing concentrations of doxorubicin $(0.625-10 \mu \mathrm{M})$ or $4-\mathrm{HC}$ (3.125-50 $\mu \mathrm{M})$. Cell viability was then assessed using an XTT colorimetric assay (Cell Proliferation Kit XTT; AppliChem, Darmstadt, Germany) that measures the activity of dehydrogenase enzymes of viable cells (37). Within each experiment, determinations were performed in duplicate or triplicate, and experiments were repeated at least five times. The percentage cell viability was defined as the absorbance of the drug-treated wells expressed as a percentage of that of controls.

Animals. Twelve- to sixteen-week-old male NSG mice (NOD.CgPrkdcscid $\left.\mathrm{Il} 2 \mathrm{rg}^{\mathrm{tm}} 1 \mathrm{Wj} / \mathrm{SzJ}\right)$ were purchased from Charles River Hungary Ltd. (Budapest, Hungary). They were maintained in the specific pathogen-free animal facility of the Biological Research Center (BRC, Szeged, Hungary). Six- to eight-week-old inbred male $\mathrm{Balb} / \mathrm{c}$ mice were obtained from the animal facility of the BRC. They received commercial mouse food pellets and water ad libitum.

In vivo experiments. All the animal experiments were performed according to Institutional and National Animal Experimentation and Ethics Guidelines, in possession of an ethical clearance (number: XVI./03521/2011). 
Table I. Cytotoxic and nuclear factor kappa-B-inhibitory effects of different aromatic aldehydes in A375 human melanoma cells.

\begin{tabular}{|c|c|c|c|c|c|c|}
\hline & \multirow[b]{2}{*}{ Compound } & \multirow[b]{2}{*}{ Structure } & \multicolumn{2}{|c|}{ Cell viability (\% of control) \# } & \multicolumn{2}{|c|}{$\begin{array}{l}\text { NFKB activity } \\
\left(\% \text { of control) }{ }^{\dagger}\right.\end{array}$} \\
\hline & & & $\begin{array}{l}\text { Aldehyde } \\
\text { alone } \\
(250 \mu \mathrm{M})\end{array}$ & $\begin{array}{c}\text { Doxorubicin } \\
(1.25 \mu \mathrm{M})+ \\
\text { aldehyde }(250 \\
\mu \mathrm{M}) \S\end{array}$ & $\begin{array}{l}\text { Basal } \\
\text { activity }\end{array}$ & $\begin{array}{l}\text { Doxorubicin- } \\
\text { induced } \\
\text { activity * }\end{array}$ \\
\hline 1 & $\begin{array}{c}2,4,6- \\
\text { Trimethoxybenzaldehyde }\end{array}$ & & 44 & 11 & 216 & 71 \\
\hline 2 & 2,5-Dimethoxybenzaldehyde & & 50 & 21 & 79 & 89 \\
\hline 3 & 2,4-Dihydroxybenzaldehyde & & 83 & 25 & 87 & 53 \\
\hline 4 & 4-Nitrobenzaldehyde & & 84 & 22 & 99 & 91 \\
\hline 5 & 2-Nitrobenzaldehyde & & 38 & 14 & 82 & 44 \\
\hline 6 & 2,4,6-Trihydroxybenzaldehyde & & 5 & 5 & 93 & 71 \\
\hline 7 & $\begin{array}{l}\text { 2-Hydroxy-3- } \\
\text { methoxybenzaldehyde (o- } \\
\text { Vanillin) }\end{array}$ & & 17 & 10 & 76 & 35 \\
\hline 8 & $\begin{array}{c}4- \\
\text { (Dimethylamino)benzaldehyde }\end{array}$ & & 104 & 36 & 103 & 114 \\
\hline 9 & 3-Quinolinecarboxaldehyde & & 77 & 30 & 79 & 61 \\
\hline 10 & $\begin{array}{c}\text { 4-Hydroxy-3- } \\
\text { methoxybenzaldehyde } \\
\text { (Vanillin) }\end{array}$ & & 104 & 26 & 96 & 100 \\
\hline
\end{tabular}

\#Cell viability was evaluated after continuous 48-h exposure to aldehyde or aldehyde plus doxorubicin. Data reported are means of 3-5 experiments. $\dagger$ Luciferase activity was evaluated after a 6 h-exposure time. Data reported are means of 3-5 determinations. *Doxorubicin concentration was 1.25

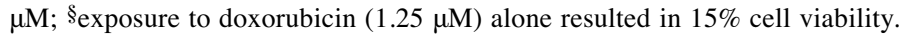




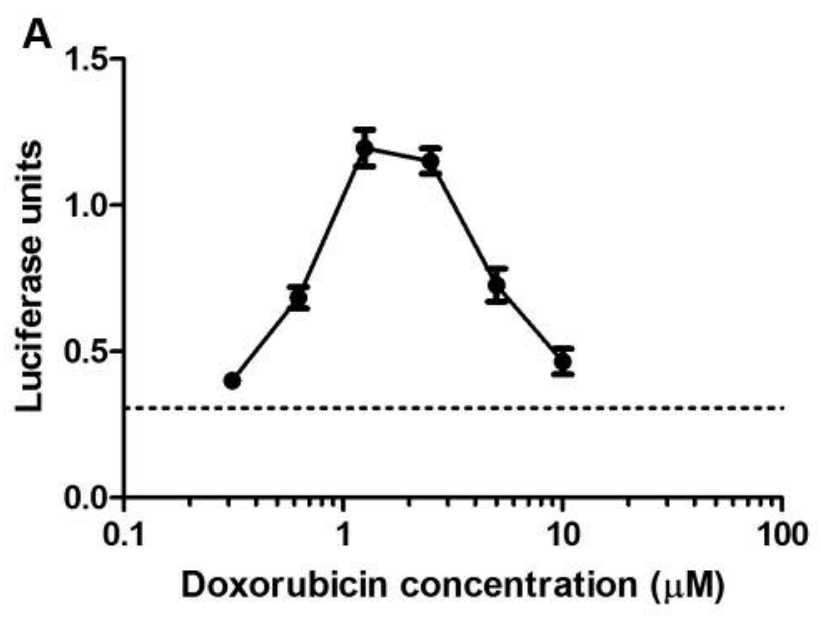

B

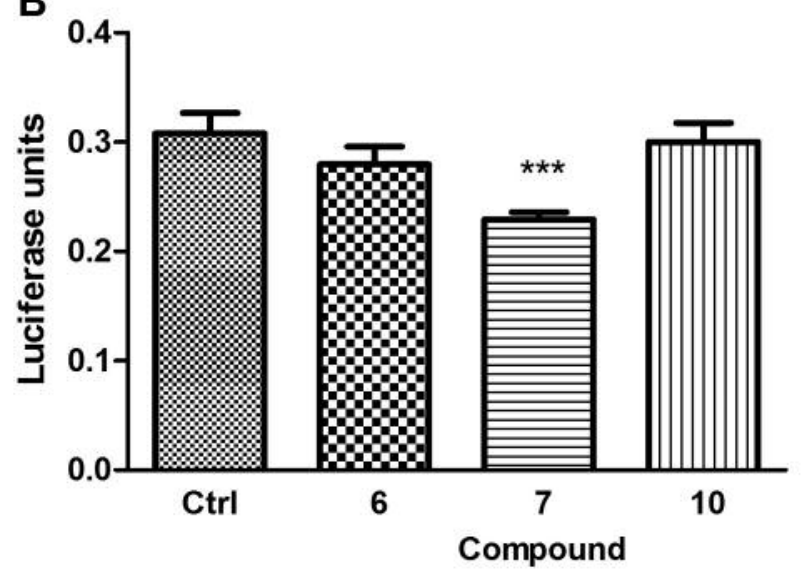

Explorative toxicology study. The in vivo antitumor activity trial was preceded by an explorative multiple-dose toxicology study carried out in healthy male Balb/c. Animals were randomly assigned to each experimental group ( $n=3$ /group) and were treated once a day orally with $o$-vanillin $(60 \mathrm{mg} / \mathrm{kg})$, TBA $(60 \mathrm{mg} / \mathrm{kg})$, or PBS (control) for 5 consecutive days followed by a 2-day wash-out. Mice were examined daily for a decrease in physical activity, weight loss, and other signs of disease. After 3 weeks of treatment, the animals were sacrificed and major organs (intestine, liver, kidneys, spleen, heart, and lungs) were visually inspected for any abnormalities. Treatmentrelated signs of toxicity were not observed, neither during the 14day treatment period, nor at macroscopic post-mortem examination.

A375 xenograft and treatment. NSG mice were subcutaneously injected with $2 \times 10^{6}$ A 375 cells suspended in $100 \mu \mathrm{l}$ of RPMI 1640 (Lonza). One day later, the animals were randomly assigned to the following experimental groups ( $\mathrm{n}=5-8 /$ group): a: $o$-vanillin $(60 \mathrm{mg} / \mathrm{kg}) ; \mathrm{b}$ : cyclophosphamide $(80 \mathrm{mg} / \mathrm{kg})$; c: $o$-vanillin $(60 \mathrm{mg} / \mathrm{kg})$ plus cyclophosphamide $(80 \mathrm{mg} / \mathrm{kg}) ; \mathrm{d}:$ TBA $(60$ $\mathrm{mg} / \mathrm{kg})$; e: TBA $(60 \mathrm{mg} / \mathrm{kg})$ plus cyclophosphamide $(80 \mathrm{mg} / \mathrm{kg})$; f: control group. The aldehydes were administered once a day orally for 5 consecutive days followed by a 2-day wash-out, starting 2 days after tumour implantation. Cyclophosphamide was administered intraperitoneally (i.p.) on day 7 and 14 after tumour

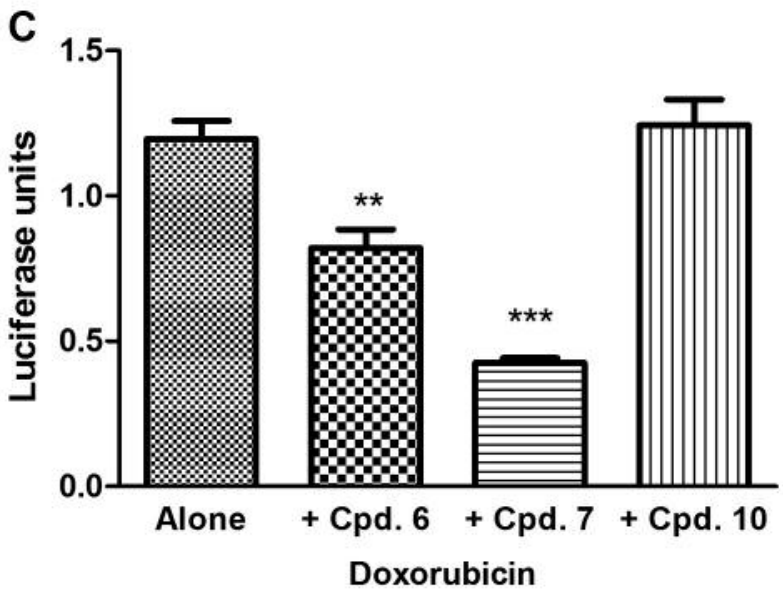

Figure 1. Effects of doxorubicin and selected aromatic aldehydes on nuclear factor kappa-B $\left(N F_{K} B\right)$ activity of $A 375$ human melanoma cells stably transfected with a NFKB-luciferase reporter construct (A375/NFKB-Luc cells). The dotted line represents the $N F_{k} B$ activity of untreated cells (basal NFKB activity). A: Doxorubicin (1.25 $\mu M$ ) caused a more than 3-fold increase of $N F_{k} B$ activity compared to control $(p<0.0001)$. B: o-vanillin (compound 7; final concentration: $250 \mu M$ ) significantly reduced basal $N F_{k} B$ activity of A375/NFKB-Luc cells $(p<0.0001 \mathrm{vs}$. control). On the contrary, vanillin (compound 10; final concentration: $250 \mu M$ ) and TBA (compound 6; final concentration: $250 \mu M$ ) did not significantly affect basal $N F_{k} B$ activity of $A 375 / N F_{k} B$ Luc cells. $C$ : Induction of $N F K B$ activity by $1.25 \mu M$ doxorubicin was significantly suppressed by $250 \mu M$ 2,4,6-trihydroxibenzaldehyde (compound 6; $p=0.0020$ vs. doxorubicin alone) or $250 \mu \mathrm{M}$ o-vanillin $(p<0.0001$ vs. doxorubicin alone). Values are mean \pm SD $(n=3)$. Statistical comparison was performed by unpaired, two tailed t-test.

cell injection; the dose and schedule of cyclophosphamide were chosen on the basis of previous optimal dose/schedule-finding experiments, which had been carried out in mice bearing 4T1 mouse mammary carcinomas (Vizler et al., unpublished data). Tumour volume was estimated from measurements made with a calliper using the formula: tumour volume $\left(\mathrm{mm}^{3}\right)=\mathrm{D} \times d^{2}$; where $\mathrm{D}$ and $d$ values were the longest and the shortest diameters of the tumour, respectively. For ethical reasons, all the animals were sacrificed at day 20 .

\section{Results}

Selected vanillin analogues remarkably inhibit $N F_{K} B$ activation and A375 human melanoma cell growth in vitro. Two widely used anticancer drugs capable of inducing NFkB activity are doxorubicin and cyclophosphamide (38). A set of experiments analyzed the impact of doxorubicin on NFkB activity in A375 human melanoma cells stably transfected with an NFkB luciferase reporter construct, both in the absence and in the presence of a fixed concentration (250 $\mu \mathrm{M})$ of each of the 10 selected aromatic aldehydes; luciferase activity was evaluated after a 6 hour-exposure 
time. As shown in Figure 1A, the maximum inductive effect of doxorubicin was observed at $1.25 \mu \mathrm{M}$, resulting in a more than 3-fold increase in luciferase activity over the basal level. This doxorubicin concentration was, therefore, selected for the subsequent assays. Six out of the 10 tested aldehydes (namely compounds 1, 3, 5, 6, 7 and 9) but not vanillin (compound 10) were effective in inhibiting the induction of NFKB transcriptional activity by doxorubicin by more than $20 \%$. Results of these experiments are summarized in the last column of Table I. Interestingly, a vanillin isomer, $o$-vanillin (compound 7), was the most potent compound, inhibiting doxorubicin-mediated induction of NFkB activity by $65 \%$ (Figure 1C). This aldehyde was also active in suppressing constitutive (basal) NFKB activity in A375 cells (Figure 1B).

The inhibitory effect of $o$-vanillin (compound 7) on chemotherapy-induced NFkB activity in A375 human melanoma cells was confirmed using 4hydroperoxycyclophosphamide (4-HC), an in vitro active analogue of the prodrug cyclophosphamide, as the NFkB activator. The maximum induction of luciferase activity by 4-HC occurred at $12.5 \mu \mathrm{M}$, where $250 \mu \mathrm{M} o$-vanillin suppressed $4-\mathrm{HC}$-induced activity by $43 \%$ (Figure 2). Based on the results of the in vitro tumour cell growth-inhibition assay (see below), a second benzaldehyde derivative, namely TBA (compound 6), was evaluated for its ability to counteract NFKB induction by 4-HC; $250 \mu \mathrm{M}$ TBA inhibited 4-HC-elicited induction of NFKB by $17 \%$ (data not shown).

The same aromatic aldehydes were further examined in vitro at a fixed concentration $(250 \mu \mathrm{M})$ for cytotoxicity as single agents and in combination with the NFKB-activating anticancer agent doxorubicin; cell viability was evaluated using an XTT assay after a continuous 48-h exposure to the studied compounds. Results of these studies are summarized in Table I. Among the tested aldehydes, only TBA and $o$ vanillin exhibited remarkable cytotoxicity when tested alone, reducing A375 cell viability to $10 \%$ or less when combined with $1.25 \mu \mathrm{M}$ doxorubicin (Table I).

$o$-Vanillin and TBA exert significant therapeutic activity in mice bearing A375 human melanoma xenografts. Based on the above-described in vitro findings, $o$-vanillin and TBA were selected for an in vivo efficacy trial in tumour-bearing mice, as single agents and in combination with cyclophosphamide; the dose and schedule of administration of the studied aldehydes were based on the results of an explorative toxicology study carried out in Balb/c mice, demonstrating no gross toxicity signs and weight loss.

As shown in Figure 3, oral administration of $o$-vanillin, or TBA, as a single agent or in combination with i.p. cyclophosphamide, delayed the growth of A375 human melanoma xenografts in immunodeficient NSG mice (see legend of Figure 3 for details on the doses and schedules of administration of each agent). It is worth noting that the

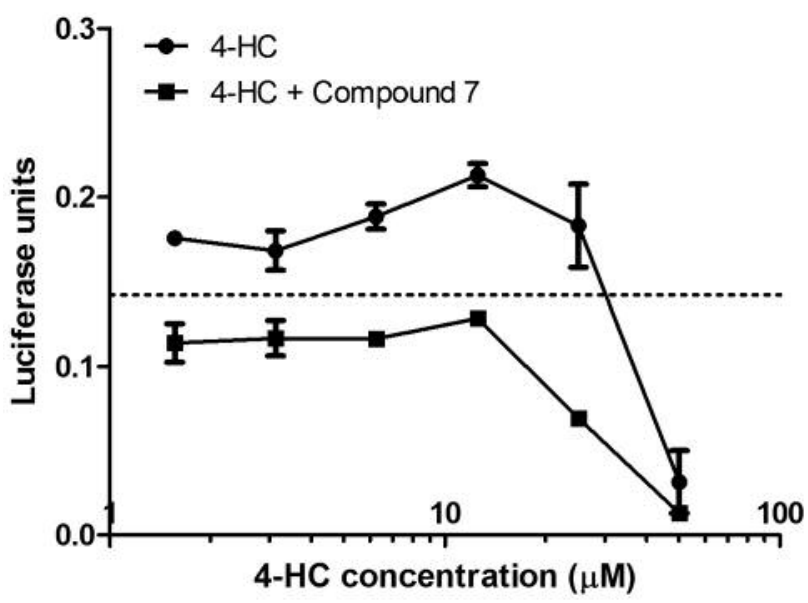

Figure 2. Impact of o-vanillin (compound 7; final concentration, $250 \mu \mathrm{M})$ on 4-hydroperoxycyclophosphamide (4-HC)-induced $N F_{K} B$ activity in A375/NFKB-Luc cells. The dotted line represents the $N F_{K} B$ activity of untreated cells (basal $N F K B$ activity). The maximum induction of $N F K B$ activity was observed at $12.5 \mu \mathrm{M} 4-\mathrm{HC}$, where ovanillin reduced the drug induced $N F K B$ activity by $43 \%$. Values are mean $\pm S D(n=3)$.

growth-delaying effect of the combination $o$-vanillin/ cyclophosphamide reached statistical significance by day 15 , and remained statistically significant until the end of the experiment (i.e. day 20). Moreover, on day 20, the antitumor effect of both tested aldehydes, as single agents, was strongly significant; the growth inhibition was $45 \%$ in the case of TBA and $32 \%$ in the case of $o$-vanillin, respectively $(p<0.0001 v s$. control). Importantly, it was comparable to that exerted by the established anticancer drug cyclophosphamide. Finally, the statistical analysis showed that on day 20, the combination of $o$-vanillin and cyclophosphamide was more effective than $o$-vanillin alone $(p<0.05)$.

\section{Discussion}

NFkB signaling pathways are constitutively active in many tumour types and have been implicated in cancer cell proliferation, invasion, metastasis and angiogenesis, as well as in suppression of cancer cell apoptosis (12). Moreover, some anticancer agents may induce chemoresistance of cancer cells through activation of NFKB $(14,16,17)$. Therefore, NFKB is currently considered an ideal target for cancer therapy (2), and various $\mathrm{NFKB}$ inhibitors targeting different components of $\mathrm{NFkB}$ activation, that is, inhibitor of kappa B kinase or NFkB subunits, are under development (39).

The observation that the widely-used natural flavouring agent vanillin (4-hydroxy-3-methoxybenzaldehyde; compound 10 , Table I) behaves as an NFKB inhibitor in both in vitro and in vivo preclinical models (34-36) led us to explore the ability 


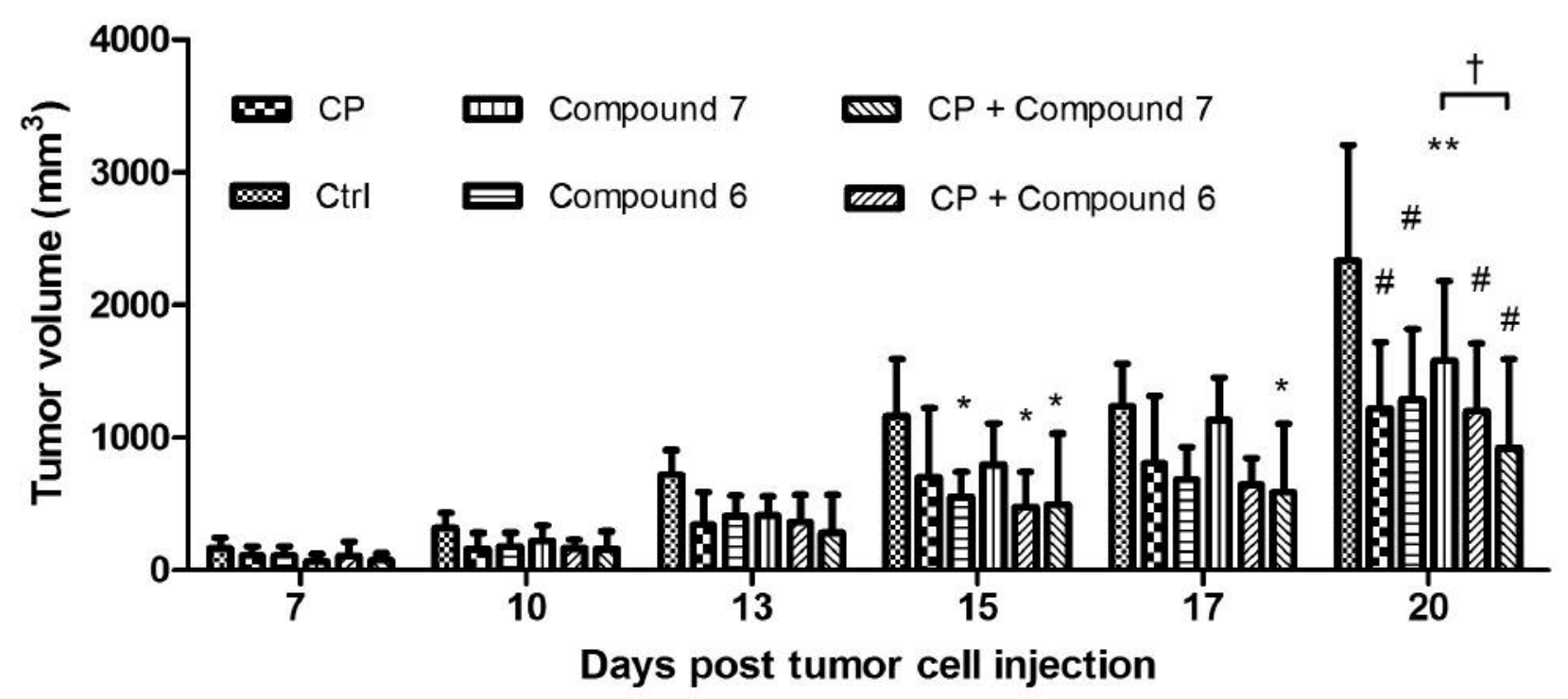

Figure 3. Effect of o-vanillin (compound 7), TBA (compound 6), cyclophosphamide (CP), o-vanillin plus CP, and TBA plus CP on A375 growth in NSG mice. A375 human melanoma cells were injected subcutaneously in the abdominal fat pad of NSG mice (day 0). One day later, the animals were randomly assigned to an experimental group (n=5-8). Compound 6 and 7 were administered orally daily at $60 \mathrm{mg} / \mathrm{kg} / \mathrm{day}$ for 5 consecutive days followed by a 2-day wash-out, starting 2 days after tumour implantation. Cyclophosphamide was administrated intraperitoneally at day 7 and 14 after tumour cell injection. Tumour volumes were evaluated as described in the Materials and Methods Section. Data are mean tumour volume $\left(\mathrm{mm}^{3}\right)$; bars, standard deviation. Results were analyzed using two-way ANOVA followed by Bonferroni post-test. ${ }^{*} p<0.05 \mathrm{vs}$. control; **p<0.01 vs. control; ${ }^{\#} p<0.01$ vs. control; ${ }^{\dagger} p<0.05$ vs. compound 6 alone.

of a small panel of aromatic aldehydes, including vanillin, to suppress chemotherapy-induced NFKB activity, and to inhibit tumour cell growth. Even though, surprisingly, vanillin was ineffective in modulating $\mathrm{NFKB}$ activity under our experimental conditions, six out of the 10 tested aldehydes (namely compounds 1, 3, 5, 6, 7 and 9) were effective in suppressing NFkB induction by the anticancer drug doxorubicin in cultured A375 human melanoma cells (Table I), with $o$-vanillin, a naturally occurring isomer of vanillin (40), being the most potent compound (Table I, and Figure 1C). The remarkable anti-NFkB activity exhibited by $o$-vanillin as well as its significant tumour growth-inhibiting activity both in vitro (Table I) and after oral administration at a non-toxic schedule to mice bearing A375 human melanoma xenografts (Figure 3) suggest that this vanillin analogue deserves further preclinical investigation as a potential antitumor drug. Although toxicological data on $o$-vanillin are scant, the published data of acute oral toxicity in mice (median oral lethal dose: $1330 \mathrm{mg} / \mathrm{kg}$ ) (41), together with the results of our explorative multiple-dose toxicology study, make this compound promising in terms of host toxicity potential.

Besides $o$-vanillin, our screening highlighted the aromatic aldehyde TBA, as a compound endowed with both a moderate ability to counteract induction of $\mathrm{NFKB}$ activity by doxorubicin or 4-HC in A375 human melanoma cells, and a remarkable in vitro and in vivo growthinhibitory activity towards the same cell line (Table I and Figure 3). TBA is one several metabolites of anthocyanins formed by gut microflora (42), and has been recently found to exhibit both in vitro antiproliferative activity towards human colorectal cancer cell lines, as well as an inhibitory effect on NFkB DNA-binding activity in Caco2 cells (43).

In conclusion, a preliminary screening of a small panel of vanillin analogues for tumour growth inhibition and suppression of NFKB signalling in A375 human melanoma cells has led to the identification of $o$-vanillin and TBA as compounds deserving further preclinical evaluation as potential anticancer agents both alone and in combination regimens. We plan to perform systematic preclinical studies in order to further explore the anticancer potential of the selected aldehydes, as well as to clarify the role of NFKB inhibition in their antitumor activity.

\section{Acknowledgements}

This work was supported by FP7-HEALTH-2012-INNOVATION-1, Proposal No: 305341-2 (CTCTrap) and NKFI-EU_BONUS_12-12013-0001; GINOP-2.3.2-15-2016-00001; OTKA 112493; TÁMOP4.2.2-A-11/1/KONV-2012-0025. 


\section{References}

1 Escarcega RO, Fuentes-Alexandro S, Garcia-Carrasco M, Gatica $\mathrm{A}$ and Zamora A: The transcription factor nuclear factor-kappa B and cancer. Clin Oncol (R Coll Radiol) 19: 154-161, 2007.

2 Garg A and Aggarwal BB: Nuclear transcription factor-kappaB as a target for cancer drug development. Leukemia 16: 10531068,2002

3 Yamamoto Y and Gaynor RB: Therapeutic potential of inhibition of the NF-kappaB pathway in the treatment of inflammation and cancer. J Clin Invest 107: 135-142, 2001.

4 Kim NK, Park JK, Shin E and Kim YW: The combination of nuclear factor kappa B, cyclo-oxygenase-2 and vascular endothelial growth factor expression predicts poor prognosis in stage II and III colorectal cancer. Anticancer Res 34: 6451-6457, 2014.

5 Karin M: Nuclear factor-kappaB in cancer development and progression. Nature 441: 431-436, 2006.

6 Fradet V, Lessard L, Begin LR, Karakiewicz P, Masson AM and Saad F: Nuclear factor-kappaB nuclear localization is predictive of biochemical recurrence in patients with positive margin prostate cancer. Clin Cancer Res 10: 8460-8464, 2004.

7 Karin M, Cao Y, Greten FR and Li ZW: NF-kappaB in cancer: from innocent bystander to major culprit. Nat Rev Cancer 2 : 301-310, 2002.

8 Wang W, Abbruzzese JL, Evans DB, Larry L, Cleary KR and Chiao PJ: The nuclear factor-kappa B RelA transcription factor is constitutively activated in human pancreatic adenocarcinoma cells. Clin Cancer Res 5: 119-127, 1999.

9 Sovak MA, Bellas RE, Kim DW, Zanieski GJ, Rogers AE, Traish AM and Sonenshein GE: Aberrant nuclear factorkappaB/Rel expression and the pathogenesis of breast cancer. J Clin Invest 100: 2952-2960, 1997.

10 Amiri KI and Richmond A: Role of nuclear factor-kappa B in melanoma. Cancer Metastasis Rev 24: 301-313, 2005.

11 Naugler WE and Karin M: NF-kappaB and cancer-identifying targets and mechanisms. Curr Opin Genet Dev 18: 19-26, 2008.

12 Basseres DS and Baldwin AS: Nuclear factor-kappaB and inhibitor of kappaB kinase pathways in oncogenic initiation and progression. Oncogene 25: 6817-6830, 2006.

13 Soengas MS and Lowe SW: Apoptosis and melanoma chemoresistance. Oncogene 22: 3138-3151, 2003.

14 Lev DC, Onn A, Melinkova VO, Miller C, Stone V, Ruiz M, McGary EC, Ananthaswamy HN, Price JE and Bar-Eli M: Exposure of melanoma cells to dacarbazine results in enhanced tumor growth and metastasis in vivo. J Clin Oncol 22: 20922100, 2004

15 Burstein E and Duckett CS: Dying for NF-kappaB? Control of cell death by transcriptional regulation of the apoptotic machinery. Curr Opin Cell Biol 15: 732-737, 2003.

16 Fujioka S, Son K, Onda S, Schmidt C, Scrabas GM, Okamoto $\mathrm{T}$, Fujita T, Chiao PJ and Yanaga K: Desensitization of NFkappaB for overcoming chemoresistance of pancreatic cancer cells to TNF-alpha or paclitaxel. Anticancer Res 32: 4813-4821, 2012 .

17 Uetsuka H, Haisa M, Kimura M, Gunduz M, Kaneda Y, Ohkawa T, Takaoka M, Murata T, Nobuhisa T, Yamatsuji T, Matsuoka J, Tanaka $\mathrm{N}$ and Naomoto Y: Inhibition of inducible NF-kappaB activity reduces chemoresistance to 5-fluorouracil in human stomach cancer cell line. Exp Cell Res 289: 27-35, 2003.
18 Huang Y, Johnson KR, Norris JS and Fan W: Nuclear factorkappaB/IkappaB signaling pathway may contribute to the mediation of paclitaxel-induced apoptosis in solid tumor cells. Cancer Res 60: 4426-4432, 2000.

19 Buchholz TA, Garg AK, Chakravarti N, Aggarwal BB, Esteva FJ, Kuerer HM, Singletary SE, Hortobagyi GN, Pusztai L, Cristofanilli $\mathrm{M}$ and Sahin AA: The nuclear transcription factor kappaB/bcl-2 pathway correlates with pathologic complete response to doxorubicin-based neoadjuvant chemotherapy in human breast cancer. Clin Cancer Res 11: 8398-8402, 2005.

20 Kumar SS, Priyadarsini KI and Sainis KB: Inhibition of peroxynitrite-mediated reactions by vanillin. J Agric Food Chem 52: 139-145, 2004

21 Chou TH, Ding HY, Hung WJ and Liang CH: Antioxidative characteristics and inhibition of alpha-melanocyte-stimulating hormone-stimulated melanogenesis of vanillin and vanillic acid from Origanum vulgare. Exp Dermatol 19: 742-750, 2010.

22 Fitzgerald DJ, Stratford M, Gasson MJ, Ueckert J, Bos A and Narbad A: Mode of antimicrobial action of vanillin against Escherichia coli, Lactobacillus plantarum and Listeria innocua. J Appl Microbiol 97: 104-113, 2004.

23 Park SH, Sim YB, Choi SM, Seo YJ, Kwon MS, Lee JK and Suh HW: Antinociceptive profiles and mechanisms of orally administered vanillin in the mice. Arch Pharm Res 32: 1643$1649,2009$.

24 Beaudry F, Ross A, Lema PP and Vachon P: Pharmacokinetics of vanillin and its effects on mechanical hypersensitivity in a rat model of neuropathic pain. Phytother Res 24: 525-530, 2010.

25 Abraham DJ, Mehanna AS, Wireko FC, Whitney J, Thomas RP and Orringer EP: Vanillin, a potential agent for the treatment of sickle cell anemia. Blood 77: 1334-1341, 1991

26 Tsuda H, Uehara N, Iwahori Y, Asamoto M, Iigo M, Nagao M, Matsumoto $\mathrm{K}$, Ito $\mathrm{M}$ and Hirono I: Chemopreventive effects of beta-carotene, alpha-tocopherol and five naturally occurring antioxidants on initiation of hepatocarcinogenesis by 2 -amino3-methylimidazo[4,5-f]quinoline in the rat. Jpn J Cancer Res 85: 1214-1219, 1994.

27 King AA, Shaughnessy DT, Mure K, Leszczynska J, Ward WO, Umbach DM, Xu Z, Ducharme D, Taylor JA, Demarini DM and Klein CB: Antimutagenicity of cinnamaldehyde and vanillin in human cells: Global gene expression and possible role of DNA damage and repair. Mutat Res 616: 60-69, 2007.

28 Shaughnessy DT, Setzer RW and DeMarini DM: The antimutagenic effect of vanillin and cinnamaldehyde on spontaneous mutation in Salmonella TA104 is due to a reduction in mutations at GC but not AT sites. Mutat Res 480-481: 55-69, 2001.

29 Shaughnessy DT, Schaaper RM, Umbach DM and DeMarini DM: Inhibition of spontaneous mutagenesis by vanillin and cinnamaldehyde in Escherichia coli: Dependence on recombinational repair. Mutat Res 602: 54-64, 2006.

30 Durant S and Karran P: Vanillins - a novel family of DNA-PK inhibitors. Nucleic Acids Res 31: 5501-5512, 2003.

31 Gustafson DL, Franz HR, Ueno AM, Smith CJ, Doolittle DJ and Waldren CA: Vanillin (3-methoxy-4-hydroxybenzaldehyde) inhibits mutation induced by hydrogen peroxide, N-methyl-Nnitrosoguanidine and mitomycin $\mathrm{C}$ but not (137)Cs gammaradiation at the CD59 locus in human-hamster hybrid $\mathrm{A}(\mathrm{L})$ cells. Mutagenesis 15: 207-213, 2000.

32 Lirdprapamongkol K, Sakurai H, Kawasaki N, Choo MK, Saitoh Y, Aozuka Y, Singhirunnusorn P, Ruchirawat S, Svasti J and 
Saiki I: Vanillin suppresses in vitro invasion and in vivo metastasis of mouse breast cancer cells. Eur J Pharm Sci 25: 57$65,2005$.

33 Lirdprapamongkol K, Kramb JP, Suthiphongchai T, Surarit R, Srisomsap C, Dannhardt G and Svasti J: Vanillin suppresses metastatic potential of human cancer cells through PI3K inhibition and decreases angiogenesis in vivo. J Agric Food Chem 57: 3055-3063, 2009.

34 Lirdprapamongkol K, Sakurai H, Suzuki S, Koizumi K, Prangsaengtong O, Viriyaroj A, Ruchirawat S, Svasti J and Saiki I: Vanillin enhances TRAIL-induced apoptosis in cancer cells through inhibition of NF-kappaB activation. In Vivo 24: 501$506,2010$.

35 Wu SL, Chen JC, Li CC, Lo HY, Ho TY and Hsiang CY: Vanillin improves and prevents trinitrobenzene sulfonic acidinduced colitis in mice. J Pharmacol Exp Ther 330: 370-376, 2009.

36 Liang JA, Wu SL, Lo HY, Hsiang CY and Ho TY: Vanillin inhibits matrix metalloproteinase-9 expression through downregulation of nuclear factor-kappaB signaling pathway in human hepatocellular carcinoma cells. Mol Pharmacol 75: 151-157, 2009.

37 Scudiero DA, Shoemaker RH, Paull KD, Monks A, Tierney S, Nofziger TH, Currens MJ, Seniff D and Boyd MR: Evaluation of a soluble tetrazolium/formazan assay for cell growth and drug sensitivity in culture using human and other tumor cell lines. Cancer Res 48: 4827-4833, 1988.

38 Romano MF, Avellino R, Petrella A, Bisogni R, Romano S, and Venuta S: Rapamycin inhibits doxorubicin-induced NFkappaB/Rel nuclear activity and enhances the apoptosis of melanoma cells. Eur J Cancer 40: 2829-2836, 2004.
39 Shen HM and Tergaonkar V: NFkappaB signaling in carcinogenesis and as a potential molecular target for cancer therapy. Apoptosis 14: 348-363, 2009.

40 Flach A, Gregel B, Simionatto E, da Silva UF, Zanatta N, Morel $\mathrm{AF}$, Linares $\mathrm{CE}$ and Alves SH: Chemical analysis and antifungal activity of the essential oil of Calea clematidea. Planta Med 68: 836-838, 2002.

$41 \mathrm{Yu}$ ZH, Gu ZP, Zhang XD and Wan F: 4-bromo-7-hydroxyindan oxime--a new potent spermicidal agent. Int J Androl 10: 741$746,1987$.

42 Forester SC and Waterhouse AL: Identification of Cabernet Sauvignon anthocyanin gut microflora metabolites. J Agric Food Chem 56: 9299-9304, 2008.

43 Forester SC, Choy YY, Waterhouse AL and Oteiza PI: The anthocyanin metabolites gallic acid, 3-O-methylgallic acid, and 2,4,6-trihydroxybenzaldehyde decrease human colon cancer cell viability by regulating pro-oncogenic signals. Mol Carcinog 53: 432-439, 2014.
Received July 15, 2016

Revised August 4, 2016

Accepted August 5, 2016 